\title{
Evaluating the Environmental Awareness and Practices of Senior High School Students: Basis for Environmental Education Program
}

\author{
Christopher Habunatalia Punzalan ${ }^{1 *}$
}

\author{
${ }^{1}$ Master of Arts in Science Education with Integrated Science, College of Graduate Studies and Teacher Education Research, Philippine Normal University, Taft \\ Avenue, Manila, PHILIPPINES \\ *Corresponding Author: punzalan.ch@pnu.edu.ph
}

Citation: Punzalan, C. H. (2020). Evaluating the Environmental Awareness and Practices of Senior High School Students: Basis for Environmental Education Program. Aquademia, 4(1), ep20012. https://doi.org/10.29333/aquademia/8219

\begin{abstract}
ARTICLE INFO
Received: 26 Apr. 2020

Accepted: 29 Apr. 2020

ABSTRACT

Environmental education in the Philippines has been incorporated to different course curricula including life and physical sciences, social studies, geography, civics, and moral education. The aim of this study was to determine the relationship between the environmental awareness and practices of Filipino senior high school students during the year 2019 to serve as basis for environmental education program. This correlation quantitative study involved SHS students in a private educational institution in the Philippines through total population sampling and utilized the Environmental Awareness and Practice Questionnaires. The results revealed that the participants have "good" level of environmental awareness $(\bar{x}=3.89)$ while "poor" extent of environmental practice $(\bar{x}=3.47)$. Using the nonparametric correlation analysis, the coefficient of 0.663 which means a "positive correlation" between the two variables was obtained. This means that the level of environmental awareness of the senior high school students is significantly and substantially related with their extent of environmental practice. Based on the summary of findings, the researcher recommends the development of environmental education programs that will both aim to maintain and increase the understanding and capacities of the students with relation to environmental problems and environmental sustainability principles.
\end{abstract}

Keywords: environmental education, environmental awareness, environmental practice, education for sustainable development, environmental sustainability

\section{ENVIRONMENTAL EDUCATION IN THE GLOBAL PERSPECTIVE}

There is big evidence that the Philippines is suffering from various environmental problems and hazards considering its topography, its people and its economic status in the global perspective. The Philippines as an archipelagic country in Southeast Asia is composed of more than 7,000 islands with a combined land and water total areas of about 300,000 square kilometers (ADB, 2009).

Grant (2012) clarified the nine principles of environmental education that contributes ideas on the environmental awareness implications to the education system. The nine principles comprised; 1) Education should highlight our interdependence with other people, other species and the planet as a whole. 2) Education should support students move from awareness to knowledge to action. Teachers, students, and schools in the world's richer countries should decrease their consumption of the world's resources. 3) Students must have prospects to improve a personal association with nature. 4) Education should be future-oriented. 5) We must relearn "old wisdoms" from native peoples to re-connect to the planet. 6) Teachers should integrate media literacy into every school subject. 7) Teachers should be facilitators. 8) Teachers should be good role models for their students and "walk their talk". 9) An environmental assessment is an important tool for measuring performance, assessing progress, and setting goals with respect to environmental practices.

In the meantime, Licy et al. (2013) on the topic of environmental protection mentioned that this matter has attained highest significance in this era globally but the practices of basic concepts like waste disposal are often ignored. The negative attitude on implementation of environmental policies uplifts the rise to chaotic situations even though the people around the globe are aware of the effect of improper waste disposal practices.

Correspondingly, Grimmette (2014) recognized the effects of environmental problems on youth and suggested endorsements to educate the youth with the concept of 
environmental education programs such as forming environmental awareness, building an association to the environment, and shifting the views and opinions of youth on the environment. The study showed significant positive effect in the three programs associated with camp curriculum including the human's influence on the water cycle, the significance of animals to humans, and disbursing time to fix problems present in nature.

Sindhu and Singh (2014) conducted an implication study which stated its importance via educational suggestions for the educational stakeholders including the teachers, educational planners, parent's educators and educational administrators. Special awareness programs in the form of seminars symposium, camps and community visits were suggested undertakings for environment teachers, students, parents and the community as well. It was reiterated that formal system of education should deliver environmental awareness to the youths and young children to cultivate the preliminary environmental education course in teacher education programs and other courses for teachers. It was established in the study that environmental education (EE) can play a significant role in decreasing and evading the current and upcoming environmental disproportions. Within the four stages of formal education such as primary education stage, lower secondary education stage, high secondary education stage, and college education stage, environmental education can be carried out.

Through the integration of environmental education in the curriculum of all school levels, an excessive influence in the understanding, practices and attitude of students towards environmental protection can be attained. It would be a great help for the students to distinguish indications on how to exercise environmental sustainability and conservation with proper environmental teaching (Raman, 2016).

According to Sharma (2004), the affective and psychomotor domains of teaching should be emphasized by the environmental educators. Teachers are simply concerned with the point that a student distinguishes and knows an assignment and can accomplish it satisfactorily but it does not mean that the student is attentive in the activity and feels confidently about it to do it again which falls under cognitive domain,. On the other hand, emotions of the learners should be stimulated to be interested, to be positive about it, and inspired to act. Thus, presentation of facts is not sufficient to achieve it.

An article by Tidball and Krasny (2010) about the Urban Environmental Education from a Social-Ecological Perspective: Conceptual Framework for Civic Ecology Education discussed a variety of environmental education practices evolving to address the needs of a progressively urban population. A conceptual framework to stimulate research questions in urban environmental education by drawing from social-ecological systems and social learning theory was proposed. The approaches such as educational programs, stewardship practice, and other social-ecological system components and processes, as well as ways by which urban environmental education could lead to community wellbeing and local ecosystem services were suggested.

\section{ENVIRONMENTAL EDUCATION IN THE PHILIPPINES}

The Philippine government had committed itself to environmental protection and natural resource management expressed through a comprehensive legal and regulatory regime in its attempt to address the numerous environmental concerns. The Environment and Natural Resources management is mandated by the Philippine Environmental Policy and the Philippine Environment Code (Presidential Decree No. 1151, 1152, s. 1977), the Philippine Strategy for Sustainable Development of 1989, Executive Order No. 15 in 1992 that created the Philippine Council for Sustainable Development (PCSD) and the National Action Plan for Sustainable Development of 1996. The Local Government Code of 1991 also contains provisions related to devolution and implementation of ENR laws and regulations. Major ENR laws signed in the past 7 years include the Ecological Solid Waste Management Act of 2000, the Wildlife Resources Conservation and Protection Act of 2001, the Public Land Act of 2002, the Philippine Clean Water Act of 2004, and the Biofuels Act of 2006. Priorities of the Department of Environment and Natural Resources (DENR) relate to major government planning frameworks including the country's Medium-Term Philippine Development Plan and the Millennium Development Goals (ADB, 2009, p. xv).

Environmental education in the Philippines has been combined into curriculum as part of other subjects such as life and physical sciences, social studies, geography, civics, and moral education, rather than a specifically isolated subject which is similar to other Southeast Asian countries. The National Strategy on Environmental Education (NSEE) which was initiated in 1989 seeks to develop a responsible and an environmentally literate citizenry that would ensure the safeguard and progress of the country's environment in order to endorse and implement sustainability, social equity, and economic efficiency in the use of its natural resources (Kong et al., 2000). With the release of the National Environmental Education Action Plan for Sustainable Development for 2005 to 2014 the obligations for sustainable development in education were reinforced, specially organized to agree with the UN Decade of Education for Sustainable Development (Didham \& Ofei-Manu, 2012).

Hinojosa (1996) emphasized the complete list of unifying themes of environmental education as honored by the Department of Environment and Natural Resources Environment Management Bureau (DENR-EMB). These themes pronounced by the agency that protects the environment happened to be the basis of research problems solved by various professionals in the field. The list includes the following themes: 1) Interdependence - Everything is related to everything; 2) Change - Everything changes. Some changes enhance the natural state of the environment, others degrade it; 3) Diversity and stability - Diversity is essential. It promotes stability; 4) Finiteness of Resources - Most of the earth's resources are finite. Therefore, they must be used prudently and wisely; 5) Materials cycle - Everything must go somewhere and ends somewhere; 6) Balance of nature - Nature has its own laws and processes to maintain it; and 7) 
Stewardship - Humans are part of nature. They are not masters, but stewards of the earth.

The two national networks for environmental education: the Environmental Education Network of the Philippines, Inc. (EENP) and the Philippine Association of Tertiary Level Educational Institutions in Environmental Protection and Management (PATLEPAM) were addition to state-led efforts that advocates for the integration of sustainable development in school programs as well as in campus management and organizational philosophy. The formation of undergraduate and graduate degree programs with an environmental focus that are now offered by academic institutions, and training programs offered by both government agencies and individual institutions are substantial advances in environmental education for sustainable development (EESD) (Galang, 2010).

Cosico (2012) emphasized in his book "Philippine Environmental Laws: An Overview and Assessment" that the Philippines must have an urgent requirement to regulate human activities aside from elevating the awareness of Filipinos since that it is located right in the typhoon belt of the Pacific and more vulnerable to natural calamities and catastrophes. The Philippine Environmental Laws which should be incorporated in environmental education programs as it pursues to discourse a great number of environmental problems ranging from deforestation, biodiversity loss and pollution types were discussed. These statements give ideas for the students to become knowledgeable about Philippine environmental policies by conducting activities in spreading these important laws.

\section{ENVIRONMENTAL AWARENESS AND PRACTICE OF FILIPINO STUDENTS}

Several studies about this concerned topic were presented by educational researchers which happened to solve problematic issues and phenomena in the environment. The study about the environmental knowledge, attitude and practices of student teachers by Esa (2010) explained that there is a need for the educational institutions to increase their efforts to educate their students for a sustainable future within this decade of Education for Sustainable Development (ESD). In order to integrate ESD effectively in the teaching upon graduation, the aspiring teachers should demonstrate proenvironmental behavior and attitudes. Good knowledge about the environment is a recommendation to ensure effective delivery. The study including the pre-service secondary teachers enrolled in an undergraduate Biology Teaching Methods course gathered and analyzed their environmental knowledge, attitude and practices. The results of the study indicated that a more concerted effort in teacher education to prepare them for their role in educating for and about the environment is a necessity.

In the same way, Pardo (2012) recognized that the depraved effect of environmental destruction is evident and its future possibilities are enormous. It is a positive alarm that the youth who endure the future accountability for the stewardship of the environment can supply their understanding to coming generations as part of sustainability.
There was a very high level of environmental awareness and good practices on the general environmental themes of the participants based on the conducted study in one of the universities in the Philippines. Cutting of trees, forest burning/forest fires, quarrying, hunting, road widening, squatting, mining, river drilling, use of inorganic fertilizer, and industrialization were activities not favored by the students. A development of an environmental education program and stable implementation of the laws and ordinances defending the environment in the University to uplift further the environmental awareness, practices, and attitudes of the students was suggested.

The study about the "Environmental Attitudes and Behaviors in the Philippines" by Reyes (2014) analyzed the attitudinal dimensions, trends and significant predictors of public and private behavior in the Philippines over the past two decades using the data from the environment modules of the International Social Survey Program in 1993, 2000, and 2010. The consistent significant predictors of negative attitudes are the perceptions of specific environmental problems and fatalism. It was found out that there were no significant increases in the environmental behaviors among Filipinos over the past two decades. It was also emphasized that the significant indicator for behaviors such as driving less, signing petitions, donating money, joining groups, and participating in public protests for the environment is the educational attainment.

On the same point, a study entitled "Environmental Awareness and Practices among High School Students: Basis for Disaster Preparedness Program” by Marpa and Juele (2016) elaborated that the effects of climate change, global warming, ozone depletion, pollution, species extinction, desertification, and improper waste management are now being experiences by the inhabitants of the mother earth. The Philippines as one of the countries vulnerable with this phenomenon is not exempted from these threats. The aim to study the environmental awareness and practise among high school students was utilized to address this problem. It was concluded in the study that there was a great extent of awareness and practices but moderate in the greening of the environment among the respondents. There was a significant correlation between the two variables and therefore the need for advocacy and integration of environmental education with an emphasis on the green technology was supported.

Gonzaga (2016) considered the Awareness and Practices in Green Technology of Students which focused on the level of awareness and extent of practices in green technology of the participants. The Bachelor of Education students of Philippine Normal University Visayas were the participants of this study and the factors which were related to the main variables of the study were sex, community, academic standing, secondary school and family income. It was revealed in this study that there was a moderate level of awareness but low extent of practices in green technology among the participants. There was also a positive correlation between the level of awareness and extent of practices obtained from the responses. The development of holistic program that incorporated the concepts and applications of green technology in college education in order to engage the students' active participation 
in the promotion of environmental sustainability was suggested by this article.

With suitable reasons that the senior high school students have inadequate knowledge on environmental practices given that the participating school of this study is initially implementing the waste segregation program, this study initiated to address the problem.

The aims of this study were to determine the environmental awareness level of the participants, their extent of environmental practice towards the environmental issues, and the relationship between their level of awareness and extent of practice on four environmental themes, and to build a basis for the proposed environmental education program in the school.

This study was conducted during the first semester of the academic year 2018 to 2019 at a private basic education institution in Dasmariñas City, Cavite, Philippines.

Moreover, this study answered the following research questions; what is the demographic profile of the respondents in terms of age, sex, grade level, academic strand and mass media exposure?; what is the level of environmental awareness of the respondents based on the core messages of environmental education in terms of four environmental themes?; what is the extent of environmental practices of the respondents based on the core messages of environmental education in terms of four environmental themes?; and what is the relationship between the level of environmental awareness and extent practice of the respondents?

\section{METHODOLOGY}

\section{Participants}

This study involved the 67 senior high school students enrolled in a Philippine private educational institution under the SHS Academic Track. Among the participants, 29 (43\%) students were from grade 11 and 38 (57\%) students were part of the grade 12 class. The students under the three different strands namely; Science, Technology, Engineering and Mathematics (STEM) were 44 (66\%), Humanities and Social Sciences (HumSS) were 12 (18\%), and Accountancy, Business and Management were 11 (16\%). When it comes to age, 30 (45\%) participants were 17 years old, 22 (33\%) participants were 16 years old and 15 (22\%) were 18 years old. In relation to sex profile, 40 (60\%) students are male while 27 (40\%) students are female. The mass media exposures of the participants were also obtained to know where they usually gather information about the environmental issues and topics. Based on the responses, 59 (88\%) students claimed that they choose internet as a form of media to collect facts referring to current status of the environment, 5 (7\%) students declared the television, 2 (3\%) students chose the radio and 1 (2\%) student for newspaper or periodical.

\section{Research Design}

This quantitative research study used a correlational descriptive design to determine the relationship between the environmental awareness and practice of senior high school students. This study revealed the present conceptions and routines of the participants towards environmental issues with accordance to the core messages of environmental education that will become a basis for the development and implementation of environmental education program in the school.

\section{Measure}

The Environmental Awareness and Practices Questionnaire adopted from Pardo (2012) in a study concerning the Environmental Awareness, Practices and Attitudes of UNP Students was utilized in this study. It included scales on environmental awareness and practices based on the four environmental themes, namely: stewardship, finiteness of resources, change and materials cycle. The purpose of this study was to measure the environmental awareness and practices of the Filipino senior high school students under the academic track and different strands. The survey questionnaire was distinctly validated by three university professionals in the Philippines with the field practices on environmental management, botany and ecology, and physical sciences.

\section{Procedure}

The participants of this research were the senior high school students in a private education institution in Dasmariñas City, Cavite, Philippines. The participants were purposely chosen to examine their current knowledge and routine towards the environmental issues. This study group was made up through whole population sampling as it consists of small number of prospective participants. The researchers administered the self-report measures to the participants via online survey with the permission of the school administrators and conducted in the school computer laboratory. The students volunteered to answer the instruments using the Environmental Awareness and Practices Questionnaire. All participants have been informed about the aims of the study before completing the measure. Descriptive statistics such as mean and nonparametric correlation analysis were utilized in this study in order to measure the relationship between the level of environmental awareness and practices of the senior high school students. The analysis was carried out using SPSS Statistics 23 . The result of the analysis was employed as a basis for the development and implementation of environmental education program in the school.

\section{RESULTS AND DISCUSSION}

The research questions of this study were answered based on the responses of the participants according to the selfassessment survey concerning their levels of environmental awareness and practices. These research questions desired to know the demographic profile of the participants in connection to the educational principles of the environment, to obtain the level of environmental awareness and practices of senior high school students, and to measure the relationship between the level of environmental awareness and extent of practices of students.

The researchers utilized different statistical analyses in order to obtain valid results from the participants' responses. 
Table 1. Descriptive interpretation for the level of environmental awareness

\begin{tabular}{ccc}
\hline Mean & Definition & Interpretation \\
\hline $4.21-5.00$ & Strongly Agree (SA) & Very High $(\mathrm{VH})$ \\
\hline $3.41-4.20$ & Agree $(\mathrm{A})$ & High $(\mathrm{H})$ \\
\hline $2.61-3.40$ & Fairly Agree (FA) & Average $(\mathrm{A})$ \\
\hline $1.81-2.60$ & Disagree (D) & Low (L) \\
\hline $1.00-1.80$ & Strongly Disagree (SD) & Very Low (VL) \\
\hline
\end{tabular}

Table 2. Descriptive interpretation for the extent of environmental practice

\begin{tabular}{ccc}
\hline Mean & Definition & Interpretation \\
\hline $4.21-5.00$ & Very Often $(\mathrm{VO})$ & Very Good $(\mathrm{VG})$ \\
\hline $3.41-4.20$ & Often $(\mathrm{O})$ & Good $(\mathrm{G})$ \\
\hline $2.61-3.40$ & Sometimes $(\mathrm{S})$ & Poor $(\mathrm{P})$ \\
\hline $1.81-2.60$ & Seldom $(\mathrm{Se})$ & Very Poor $(\mathrm{VP})$ \\
\hline $1.00-1.80$ & Never $(\mathrm{N})$ & Needs Improvement $(\mathrm{NI})$ \\
\hline
\end{tabular}

The measure of central tendency which obtained the mean values of the awareness and practices levels of the respondents on the four environmental themes was used in order to descriptively reveal their results based on the descriptive interpretations for environmental awareness and practice. Nonparametric correlation analysis was utilized in order to get the significant inter-correlation values between the two variables.

The level of environmental awareness and extent of practices of senior high school students are presented in four environmental themes as shown in Table 3.

In the first environmental theme about stewardship or man as God's caretaker, results displayed that the respondents have "high" level of awareness with a mean rating of 3.75 and agree that they are tasked to protect the living things and its environment as stewards of the earth. On the other hand, the respondents have "good" extent of practice with a mean rating of 3.61 and often follow ecological practices like minimizing the use of pesticides/insecticides.

The second environmental theme is about the finiteness of resources or the earth as place for the future generations as well. Results showed that the participants have "high" level of awareness with a mean rating of 4.04 and they strongly agree that the earth and its resources must be sustainably used so that the future generations may still have enough sources of means for living. In terms of the extent of practice, the respondents have "good" extent of practice with a mean rating of 3.78 and often contribute to the growing of seedlings for the next seasons' use of fishes and other marine organisms.

The third environmental theme covered the changing phenomena on earth which disclosed that the respondents have "high" level of awareness supported by the mean rating of 3.57 and they agree that the earth is in the present condition where a lot of changes happen most particularly on the climate and environment. There is a "poor" extent of environmental practice among the respondents in the third theme with a mean rating of 3.07 as they sometimes exercise green practices such as walking when travelling short distances to help regulate oil resources and cooking firewood rather than using LPG.

Lastly, the Materials Cycle or Everything Must Go Somewhere and Ends Somewhere as the fourth environmental theme indicated "high" level of environmental awareness of respondents with a mean rating of 4.08 and agree that waste materials that are disposed properly can help save the environment. The result for the extent of practice is supported by the mean rating of 3.49 which is "good" as the students are often being responsible to pick up liters and put them in the trashcan and sell empty bottles, tins, old newspapers instead of putting them in garbage can as good practice of material cycle.

Generally, the level of environmental awareness on the four environmental themes among the respondents is found to be "high" with an overall mean rating of 3.89. The result is derived from same interpretations in terms of the four environmental themes as the basis. However, the extent of environmental practice on the four environmental themes among the respondents is found to be "good" with an overall mean rating of 3.47 . The result is derived from the three environmental themes while the third theme as "change" received the lowest level or poor interpretation.

Table 3. Group N, M, and DI on the level of environmental awareness and extent practices of senior high school students towards the four environmental themes

\begin{tabular}{|c|c|c|c|c|}
\hline \multirow{2}{*}{$\begin{array}{l}\text { Level of Environmental Awareness and Extent of Practices on the Four Environmental } \\
\text { Themes }(\mathrm{N}=67)\end{array}$} & \multicolumn{2}{|c|}{ Awareness } & \multicolumn{2}{|c|}{ Practices } \\
\hline & Mean & DI & Mean & DI \\
\hline A. Man: God's Caretaker (Stewardship) & 3.75 & $\mathrm{H}$ & 3.61 & $\mathrm{G}$ \\
\hline B. The Earth - For the Future Generations Too (Finiteness of Resources) & 4.04 & $\mathrm{H}$ & 3.78 & G \\
\hline C. Most of the Earth's Resources are now Depleting (Change) & 3.57 & $\mathrm{H}$ & 3.07 & $\mathrm{P}$ \\
\hline D. Everything Must Go Somewhere and Ends Somewhere (Materials Cycle) & 4.08 & $\mathrm{H}$ & 3.49 & G \\
\hline Overall & 3.89 & $\mathrm{H}$ & 3.47 & $\mathrm{G}$ \\
\hline
\end{tabular}

Table 4. Significant relationship between the awareness and practice of the respondents towards the four environmental themes

\begin{tabular}{|c|c|c|c|c|}
\hline \multicolumn{3}{|c|}{ Nonparametric Correlation } & \multirow{2}{*}{$\begin{array}{c}\text { Awareness } \\
1.000\end{array}$} & \multirow{2}{*}{$\frac{\text { Practice }}{.663^{* * * *}}$} \\
\hline \multirow{6}{*}{ Spearman's rho } & \multirow{3}{*}{ Awareness } & Coefficient & & \\
\hline & & Sig. (2-tailed) &. & .000 \\
\hline & & $\mathrm{N}$ & 67 & 67 \\
\hline & \multirow{3}{*}{ Practice } & Coefficient & $.663^{* * *}$ & 1.000 \\
\hline & & Sig. (2-tailed) & .000 & . \\
\hline & & $\mathrm{N}$ & 67 & 67 \\
\hline
\end{tabular}

\footnotetext{
***. Correlation is significant at the 0.01 level (2-tailed)
} 
Meaningfully, the researchers utilized a nonparametric correlation analysis to know if there is a significant relationship between the level of environmental awareness and extent of practices among the senior high school students. The analysis indicated a Spearman's rho coefficient of 0.663 which shows a "positive correlation" between the two variables as shown in Table 4. This means that the level of awareness of the senior high school students is significantly and substantially related to their extent of practice along the four environmental themes namely: stewardship, finiteness of resources, change, and materials cycle.

\section{CONCLUSIONS AND RECOMMENDATIONS}

It is a main objective of the study to know if there is a significant relationship between the level of awareness and extent of practices among the senior high school students in terms of the four environmental themes. As the researchers realize the objective, the results illustrated that there is a positive correlation between the environmental awareness and practice among the respondents. The researchers concluded that the present knowledge of the students on environmental problems and issues meet the appropriate level of practice even though there is one theme "change" that obtained a lower level than the three other themes. It is proven that what the students know about environmental problems can be able to transform into actions which allow them to solve these issues with their existing knowledge.

This means that the respondents' high level of environmental awareness has a connection on their good environmental practice. The results follow the findings from the study of Pardo (2012) which established a significant and substantial relationship between the awareness and practice towards environmental issues among the selected students of the University of the Northern Philippines.

Based on the summary of findings and conclusions, the researchers recommend for the development of environmental education program which will not only maintain but also to increase the level of awareness and extent of practice of the senior high school students towards the environmental problems and sustainable development principle. This can be done by offering elective subjects inclined with environmental education as part of the senior high school curriculum most especially for the students under the Science, Technology, Engineering and Mathematics (STEM) strand as they are more exposed to the similar learning competencies.

As it is not enough to educate only the learners inside the classroom about these issues, it is also suggested that the promotion of environmental stewardship can be executed within the school premises by implementing such policies like zero waste practice, bring your own bottle and waste segregation program. The school officials and teachers are also encouraged to extend the classroom settings to outside activities and programs like becoming part of tree or mangrove planting activity and coastal clean-ups. A conduct of policy review on various legislations comprising of education and other sectors such as environment department and local government units should be realized in order to assess whether the policies are still implemented effectively in the schools and institutions involved.

\section{REFERENCES}

Asian Development Bank Report (ADB). (2009). 5th Country environmental analysis: Philippines 2008. ADB, Manila. Retrieved from: http:/www.adb.org/sites/default/files/pub /2009/5th-Country-Environmental-Analysis-PHI.pdf

Cosico, R. V. (2012). Philippine environmental laws: An overview and assessment. Central Book Supply, Inc.

Didham, R. J., \& Ofei-Manu, P. (2012). Education for sustainable development country status reports: An evaluation of national implementation during the UN decade of education for sustainable development in East and Southeast Asia. UNU-IAS/IGES Research Project on Monitoring and Evaluation of ESD. Hayama, IGES.

Esa, N. (2010). Environmental knowledge, attitude and practices of student teachers. International Research in Geographical and Environmental Education, 19(1), 39-50. https://doi.org/10.1080/10382040903545534

Galang, A. P. (2010). Environmental education for sustainability in higher education institutions in the Philippines. International Journal of Sustainability in Higher Education, 11(2), 173-183. https://doi.org/10.1108/ 14676371011031892

Gonzaga, M. L. (2016). Awareness and Practices in Green Technology of College Students. Applied Mechanics and Materials, 848, 223-227. https://doi.org/10.4028/www. scientific.net/AMM.848.223

Grant, T. (2012). Nine principles for environmental education. Green Teacher Magazine, 29, 10. Retrieved from: http://gilesig.org/29Nine.htm

Grimmette, K. A. (2014). The impacts of environmental education on youth and their environmental awareness (Unpublished Undergraduate Thesis). University of Nebraska-Lincoln.

Hinojosa, B. (1996). Environmental ethics and its relation to environmental education. Philippine Department of Environment and Natural Resources - Environmental Management Bureau.

Kong, L., Poh Ai, I., Gusti Tisna, P., Remorin, P., Suwannatachote, R., \& Lee, W. (2000). In Yencken, D., Fien, J., \& Sykes, H. (Eds.). Environment, education and society in the Asia-Pacific: Local traditions and global discourses (pp. 113-134). London: Routledge.

Licy, C. D., Vivek, R., Saritha, K., Anies, T. K., \& Josphina, C. T. (2013). Awareness, attitude and practice of school students towards household waste management. Journal of Environment, 2, 147-150.

Marpa, E. P., \& Juele, M. H. R. (2016). Environmental awareness and practices among high school students: Basis for disaster preparedness program. Applied Mechanics and Materials, 848, 240-243. https://doi.org/10.4028/www. scientific.net/AMM.848.240 
Pardo, C. G. (2012). Environmental awareness, practices, and attitudes of selected UNP students. UNP Research Journal, $21,145-164$.

Raman, R. A. (2016). Attitudes and behavior of Ajman University of Science and Technology Students towards the environment. IAFOR Journal of Education, 4(1). https://doi.org/10.22492/ije.4.1.04

Reyes, J. L. (2014). Environmental attitudes and behaviors in the Philippines. Journal of Educational and Social Research, 4(6), 87-102. https://doi.org/10.5901/jesr.2014.v4n6p87
Sharma, R. C. (2004). Implications of environmental education in teacher education. Journal of Indian Education, 5-13.

Sindhu, P., \& Singh, S. (2014). A study of awareness towards environmental education among the students at secondary level in Gurgaon district. International Journal of Scientific and Research Publications, 4(1).

Tidball, K. G., \& Krasny, M. E. (2010). Urban environmental education from a social-ecological perspective: conceptual framework for civic ecology education. Cities and the Environment, 3(1). https://doi.org/10.15365/cate.31112010 